\author{
RAFAŁ LEŚNICZAK \\ Uniwersytet Kardynata Stefana Wyszyńskiego w Warszawie (Polska) \\ R.LESNICZAK@UKSW.EDU.PL \\ HTTPS: / / ORCID.ORG/ 0000-0003-0099-4327
}

\title{
Etyczne aspekty mediatyzacji życia religijnego - uwagi do dyskusji
}

\author{
Ethical Aspects of Mediatization of Religious Life - \\ Comments for the Discussion
}

\begin{abstract}
Abstrakt. Celem artykułu jest refleksja nad ważnymi etycznymi aspektami mediatyzacji życia religijnego, do których zaliczono: obecność sacrum w przestrzeni profanum; prawdę jako punkt odniesienia dla medialnych interpretacji doktrynalnych podstaw religii; determinanty życia religijnego w przestrzeni mediów. Artykuł ma charakter przeglądowy. Wykorzystano metodę analizy i syntezy. Udowodniono, że korespondencyjna definicja prawdy stanowi ważny punkt odniesienia w pytaniu o rzetelność informowania o religii. Religijne kwestie o charakterze doktrynalnym domagają się od mediów wierności przekazu, a pozostałe kwestie religijne pozwalają na większą swobodę interpretacyjną. Podstawowe determinanty życia religijnego (tożsamość i wynikająca z niej autodeklaratywność wiary, formalna przynależność osoby do danej religii, indywidualne i wspólnotowe praktyki religijne) wymagają od nadawców nie tylko wiedzy z obszaru nauk o komunikowaniu, lecz także stosownej wiedzy religijnej, procesy mediatyzacji dotyczące życia religijnego mają bowiem określone granice użyteczności i stosowalności.
\end{abstract}

Słowa kluczowe: etyka; mediatyzacja; profanum; religia; sacrum

\begin{abstract}
The aim of the article is to reflect on important ethical aspects of mediatization of religious life, which include: the presence of the sacrum in the space of profanum; the truth as a reference point for media interpretations of the doctrinal foundations of religion; factors of religious life in the media space. This text is a review article. The method of analysis and synthesis was used. It has been proven that the correspondence definition of truth is an important point of reference in the question of the reliability of reporting about religion. Religious doctrinal issues demand media fidelity to the message, while other religious issues allow greater freedom of interpretation. The basic determinants of religious life (identity and the resulting self-declarativeness of faith, formal affiliation of a person to a specific religion, individual and community religious practices) require from broadcasters not only knowledge in the field of communication sciences, but also relevant religious knowledge. The mediatization processes concerning religious life have certain limits of usefulness and applicability.
\end{abstract}

Keywords: ethics; mediatization; profanum; religion; sacrum 


\section{Wprowadzenie}

Pandemia koronawirusa COVID-19, która dotknęła w 2020 r. międzynarodową społeczność, przyczyniła się do światowej kwarantanny, wyrażającej się m.in. w zamknięciu granic, dystansie społecznym, zdalnych formach nauczania w szkołach i na uniwersytetach, zawieszeniu normalnego funkcjonowania wielu sektorów gospodarki i usług oraz organizowania imprez masowych. Z punktu widzenia wyznawców różnych religii epidemia spowodowała brak możliwości bezpośredniego udziału w publicznym kulcie. Na przykład z powodu COVID-19 jedna z muzułmańskich praktyk o największym znaczeniu, czyli pielgrzymka do Mekki, została decyzją władz saudyjskich z dnia 27 lutego 2020 r. tymczasowo zawieszona (Chulov, 2020). Władze Iraku z kolei zaprzestały organizacji pielgrzymki do świętego miasta Karbali (BBC News, 2020). Podczas pandemii wprowadzono decyzje dotyczące zawieszenia organizowania zbiorowych modłów w meczetach (Nasrullah, 2020). Papież Franciszek przewodniczył nabożeństwom Wielkiego Tygodnia oraz Świąt Wielkanocnych bez udziału wiernych (Vatican News, 2020). W wielu państwach na czas epidemii zostały zamknięte miejsca kultu (m.in. we Włoszech, w Kuwejcie, Niemczech, Iranie) lub wprowadzono znaczące limity (np. w Polsce, Francji czy na Węgrzech) (Burke, 2020; KAI, 2020). Przywódcy największych religii apelowali do wiernych o korzystanie z mediów podczas wprowadzonego lockdownu. Badania dotyczące religijnych praktyk wiernych Kościoła katolickiego w Polsce uwyraźniły znaczący wzrost użytkowników telewizji i Internetu podczas transmisji mszy świętych w czasie pandemii COVID-19:

Jak wynika z danych Nielsen Audience Measurement - udostępnionych portalowi Wirtualnemedia.pl przez Mediacom - średnia widownia mszy świętej emitowanej w niedziele o godz. 7.00 w TVP1 w dniach 15 i 22.03.2020 wyniosła 1,65 mln widzów, co przełożyło się na 34,04 proc. udziału wśród wszystkich widzów, 15,53 proc. w grupie wiekowej 16-49 lat oraz 18,90 proc. w grupie 16-59 lat. Dla porównania, w okresie od 1.01.2020 do 8.03.2020 (emisja w niedziele i święta o godz. 7.00), transmisje śledziło średnio 435 tys. osób, co dało stacji odpowiednio 18,11 proc., 4,01 proc. i 6,32 proc. udziału. Widownia mszy w okresie epidemii koronawirusa zwiększyła się niemal czterokrotnie. (Kurdupski, 2020)

Raport A. Selsky'ego (2020) z amerykańskiej agencji prasowej Associated Press dowodzi, że wzrost liczby użytkowników religijnych transmisji online podczas pandemii dotyczy wszystkich największych światowych religii: chrześcijaństwa, islamu, hinduizmu, buddyzmu i judaizmu. Tytułem przykładu dziennikarz przywołał dane liczbowe zebrane przez O. Suleimana, przywódcę islamu w Irving w Teksasie, które odnoszą się do liczby wyświetleń filmów na YouTube przesłanych przez Yaqeen Institute for Islamic Research - przez cały rok 2019 zostały one wyświetlone $30 \mathrm{mln}$ razy, a w okresie zaledwie sześciu tygodni pandemii (4.04.2020-16.05.2020) odnotowano 20 mln wejść. 
COVID-19 w znaczący sposób wyeksponował zatem związek życia religijnego i mediów. Relacje pomiędzy mediami i religią są przedmiotem badań wielu uznanych medioznawców i socjologów religii (Hoover, 2006; Hepp, Hjarvard \& Lundby 2010; Hjarvard, 2011; Lövheim \& Hjarvard, 2019).

W niniejszym opracowaniu podjęto refleksję nad ważnymi etycznymi aspektami mediatyzacji życia religijnego. Do zagadnień wpisujących się w przestrzeń aksjologicznego namysłu nad tą kwestią można zaliczyć: obecność sacrum w przestrzeni profanum; prawdę jako punkt odniesienia dla medialnych interpretacji doktrynalnych podstaw religii; determinanty życia religijnego w przestrzeni mediów. Artykuł ma charakter przeglądowy. Wyeksponowano wybrane kwestie jako postulowane do dalszej refleksji medioznawczej, nie traktując jednocześnie zaproponowanych kierunków badań jako jedynego i wyłącznego horyzontu badań. W pierwszej części wyjaśniono kwestie terminologiczne, a w drugiej wybrane kwestie dyskusyjne dotyczące etycznych aspektów mediatyzacji życia religijnego, w trzeciej zaś zaprezentowano wnioski.

\section{Kwestie terminologiczne}

Zgodnie z definicją W. Pisarka mediatyzacja to „proces pośrednictwa mediów w poznawaniu świata; wpływanie przez media na postrzeganie przez człowieka rzeczywistości niedostępnej bezpośredniemu doświadczeniu wraz z konsekwencjami takiego pośrednictwa; kształtowanie obrazu całej rzeczywistości społecznej, a nawet kompleksowych doświadczeń społecznych pod wpływem konstrukcji medialnych" (Pisarek, 2006, s. 118). Przyjęta na użytek niniejszej analizy definicja mediatyzacji autorstwa nestora polskiego prasoznawstwa świadczy o zogniskowaniu uwagi autora na zrozumieniu bardziej mechanizmu pośrednictwa mediów niż zmiany społecznej wywołanej zmianą w mediach, w tym w przekazie mediów. W ujęciu W. Pisarka proces mediatyzacji można rozpatrywać na kilku poziomach: nadającego przekaz, odbiorcy oraz technologii. Jeśli bowiem na sytuację komunikacyjną spoglądamy w perspektywie teoretycznej, to dostrzegamy w niej fundamentalne elementy ją konstytuujące: nadawcę, komunikat, kontekst, kod, kanał i odbiorcę (Bachura, 2011). Podział procesu mediatyzacji na poziom nadawcy, odbiorcy i technologii należy odczytywać nie jako wyizolowane od siebie i niepowiązane ze sobą przestrzenie analizy, lecz raczej jako „system naczyń połączonych”, w którym pomocne dla zrozumienia ich wzajemnych powiązań są zjawiska konwergencji mediów oraz model komunikacji opartej na interakcji nadawcy z odbiorcą (Iwaszko, 2010; Kopecka-Piech, 2011). Z kolei „doświadczenie społeczne”, o którym wspomina W. Pisarek, prędzej czy później zmierzać będzie w stronę podejścia konstruktywnego (Kopecka-Piech, 2015).

Religię potraktowano jako przeżywaną w wymiarze indywidualnym i wspólnotowym osobową relację jednostki do Boga, natomiast życie religijne jako jego praktyczną realizację (Kamiński \& Zdybicka, 1974). Do podstawowych elementów życia religij- 
nego zaliczono: tożsamość religijną, deklarowaną i urzeczywistnianą przynależność do wspólnoty religijnej oraz wypełnianie obligatoryjnych praktyk religijnych.

Jako nadawcę autor przyjął w analizie osobę dziennikarza, instytucjonalne źródło informacji przekazujące wiadomości na temat życia religijnego bądź wytwórcę dyskursu. Z kolei pod pojęciem odbiorcy autor rozumie grupę docelową, audytorium dysponujące określonym zasobem wiedzy, mające konkretne usytuowanie społeczne, zainteresowania, kompetencję komunikacyjną oraz potrzeby intelektualne i emocjonalne. Odbiorcą jest zatem w podjętym obszarze badań wyznawca danej religii, który od przekazu medialnego oczekuje zaspokojenia potrzeb dotyczących życia religijnego, np. przekazu wiedzy na temat religii czy też transmisji najważniejszych form kultu religijnego. Natomiast technologia to kanały dystrybucji przekazu, szeroko rozumiany kontekst kulturowy dyskursu oraz bardziej specyficzny kontekst sytuacyjny (Lisowska-Magdziarz, 2006).

\section{Obecność sacrum w przestrzeni profanum}

W literaturze filozoficznej eksponuje się podział rzeczywistości na sacrum i profanum. Są to dwie sfery intuicyjnie odnoszone do sfery świętej i świeckiej. Według M. Eliadego (1999) sacrum i profanum to dwa sposoby bycia w świecie, dwie sytuacje egzystencjalne. Dokonując metafizycznej analizy człowieka jako bytu otwartego na transcendencję, R. Otto (2004) zauważył, że istnieje w nim głębokie przeczucie istnienia wyższego bytu, które bazuje na kognitywistyce pozarozumowej. Z kolei zdaniem G. Löhra doświadczenie religijne związane jest z głębią świadomości człowieka, który uznaje Boga za fundament duchowej rzeczywistości:

Człowiek religijny ma swoje prawo do istnienia, ponieważ Bóg jest najgłębszym fundamentem świata i zarazem fundamentem duszy człowieka. (...) Człowiek może w ogóle doświadczyć bóstwa tylko wtedy, gdy objawi mu się ono w głębi jego świadomości [Der religiöse Mensch hat seine Existenzberechtigung, weil Gott der tiefste Grund der Welt ist und zugleich der Seelengrund des Menschen. (...) Der Mensch kann also die Gottheit überhaupt nur erfahren, wenn sie sich ihm in der Tiefe seines Bewusstseins offenbart]". (Löhr, 1993, s. 118)

Niematerialny wymiar doświadczenia religijnego uzewnętrzniany jest w praktykach religijnych. Wewnętrzna relacja osoby ludzkiej z Bogiem, a także jej zewnętrzne przejawy zostają asocjowane z terminem sacrum. To co nie należy do sfery świętej, zaliczone zostaje do sfery profanum. Procesy mediatyzacji, uwyraźniające znaczącą rolę mediów w procesach komunikowania, nie przynależą do sfery sacrum, lecz jako przynależące do sfery profanum mogą wpływać na doświadczenie religijne człowieka w sensie tworzenia przez człowieka klucza interpretującego jego stosunek do świata 
i Boga. Profanum wpływa na sacrum m.in. w wymiarze duchowym, psychologicznym i socjologicznym. Mediatyzacja zwykle oznacza eliminację sacrum z życia człowieka, a jej konsekwencją są indywidualizacja i prywatyzacja religii, co oznacza, że dana osoba traktuje przeżywanie własnego odniesienia do Absolutu jako kwestię prywatną, do której dostępu nie ma wspólnota lub jest on znacznie zredukowany (Motak, 2010). Jak wskazuje D. Guzek, proces mediatyzacji prowadzi do redukcji wspólnotowego wymiaru modlitwy na rzecz zindywidualizowanych działań. W opinii polskiego medioznawcy „problematyczną okazuje się realizacja podstawowej funkcji religii, jaką jest łączenie ludzi” (Guzek, 2015, s. 76), a także mieszanie się sfer sacrum i profanum. Konsekwencją synkretyzmu powyższych obszarów będzie z jednej strony „skracanie” fizycznego dystansu między wyznawcą danej religii a świątynią, między komunikatami nadawanymi przez lidera religijnego a członkami wspólnoty. W tym znaczeniu media przyczyniają się do dywulgacji doświadczenia religijnego. $Z$ drugiej strony media, jako przynależące do sfery profanum, mogą jednak traktować wartości religijne, będące częścią życia religijnego, instrumentalnie, manipulacyjnie, konsumpcyjnie i skandalicznie, co uwyraźnia antagonizm pomiędzy sferami profanum i sacrum (Jęczeń, 2011). Dobrą egzemplifikacją tej sytuacji są kontrowersyjne kampanie reklamowe, które wykorzystują symbole religijne (Stępniak, 2018a). Zazwyczaj motywy religijne w mediach świeckich, a zatem reprezentujących obszar profanum, cechuje deprywacja uprzednio posiadanej tożsamości oraz redukcja wyłącznie do roli znaku. D. Guzek (2013, s. 313) określił taki sposób wykorzystania symboli sakralnych mianem „symbolicznego regresu". Zdaniem K. Stępniaka sacrum w reklamie komercyjnej ma za cel „przyciągnąć uwagę odbiorcy, czasem wywołać szum medialny, szokować czy wprost oburzać. A wszystko po to, by reklama mogła »żyć«, by było o niej głośno. Zazwyczaj tak rozumiane "sacrum " jest częścią reklamy szokującej (shockvertising)" (Stępniak, 2018b, s. 331).

Relacje pomiędzy sacrum i profanum należy współcześnie rozpatrywać w kontekście ery postsekularnej, redefinicji pojęcia religii (które bywa traktowane wyłącznie jako jedna z form duchowości) (Rogińska, 2014), idei sekularyzmu odwołującej się do Weberowskiej koncepcji entzauberte Welt (Vahland, 2001) czy postulatów ponowoczesnej konfrontacji wiedzy i wiary, negującej filozoficzną anzelmiańską formułę fides quaerens intellectum (Rogińska, 2014). W przypadku nurtów typu New Age, reprezentujących duchowość maksymalną, następuje synteza wiary i wiedzy oraz zmiana paradygmatu współczesnej nauki - krytyka optyki redukcjonistycznej i dualistycznej (Rogińska, 2014). Odnotowuje się ponadto nurt duchowości, który nie tylko chce wyjaśnić świat ludzki, lecz także go usprawiedliwić. Stąd, zdaniem niemieckiego filozofa J. Habermasa (2002), samo profanum nie wystarcza człowiekowi. W wymiarze zmediatyzowanej rzeczywistości religijnej odnotowuje się przeżywanie sacrum wirtualnego w sposób realny i duchowy, choć faktycznie nie jest ono sacrum nadprzyrodzonym, a jedynie konsekwencją konwergencji technologii cyfrowej i duchowości (Rogińska, 2014). 


\section{Prawda jako punkt odniesienia medialnych interpretacji doktrynalnych podstaw religii}

Spośród wielu koncepcji prawdy, klasyczne (korespondencyjne) rozumienie tego pojęcia dość często przyjmowane jest jako horyzont badawczy. Jak zauważa S. Judycki (2001, s. 28), „pojęcie prawdy w sensie klasycznym nie tylko nie da się wyeliminować z naszego myślenia o świecie, lecz także pociąga za sobą pewne przekonania, które zbiorczo można nazwać racjonalizmem metafizycznym". W takim ujęciu prawda jest cechą sądu polegającą na zgodności pomiędzy treścią tego sądu a faktem, do którego treść się odnosi (Judycki, 2001, s. 29).

Istotnym problemem, przybierającym na sile szczególnie w drugiej dekadzie XXI stulecia, $\mathrm{w}$ kontekście etycznych wymiarów mediatyzacji, $\mathrm{w}$ tym dotyczących życia religijnego, jest fake news. Termin ten bywa w różny sposób definiowany, m.in. jako: wiadomość medialna oparta na dezinformacji, często zawierająca fragmenty nieprawdziwe; zabieg manipulowania faktami w celu zwiększenia zainteresowania opinii publicznej; świadome wprowadzanie odbiorcy przekazu w błąd, aby uzyskać partykularne korzyści; świadoma implementacja kłamstwa w przestrzeni medialnej; świadome ukrywanie informacji w akcie komunikowania w określonym celu; stosowanie fałszywego przekazu w celu wykreowania określonych postaw społecznych (Bąkowicz, 2019). Różnorodność definicyjna fake newsa posiada wspólny mianownik, tj. odrzuca klasyczne rozumienie prawdy adaequatio rei et intellectus $\mathrm{w}$ ujęciu św. Tomasza z Akwinu (Bartel, 2007).

Problem fake newsa jest w znaczącej mierze związany z czynnikiem ludzkim, a nie wyłącznie z ekosystemem technologicznym (Soler, 2018). Błędem byłoby powiązanie problemu etyczności cyrkulacji fałszywych informacji wyłącznie $\mathrm{z}$ ich nadawcami i pomijanie odpowiedzialności użytkowników mediów. Naiwność i brak weryfikacji wiarygodności serwisów informacyjnych to istotne przejawy niedostatku edukacji medialnej po stronie odbiorców (Ptaszek, 2014). Problem ten należy powiązać z pytaniem o wybór modelu formacji dziennikarskiej oraz o to, czy jego fundament powinna stanowić prawda rozumiana w sensie korespondencyjnym (Leśniczak, 2011; Furman, 2017).

G. Gili i G. Maddalena (2018) wyróżniają różne formy kłamstw, które przyporządkowują do fake newsów. Są to faktoidy, zafałszowania i pominięcia. Pierwsze $\mathrm{z}$ nich są symulacjami wydarzeń, które nigdy się nie wydarzyły. Faktoidy są w obszarze nauk o komunikowaniu rodzajem halucynacji. Coś co nie istnieje, staje się „rzekomo prawdziwym wydarzeniem", ponieważ ktoś uczynił je faktem i jest rzeczywiste w odniesieniu do konsekwencji i skutków, które przynosi (Gili, 2001). Z kolei zafałszowania oznaczają jakościowe lub ilościowe zmiany danych rzeczywistości. Technika ta oznacza, również na poziomie zastosowanego języka, słowne i pisemne, celowe ukrywanie lub eksponowanie niektórych zwrotów, umieszczanie wiadomości w określonym kontekście, w intencjonalnie zastosowanych ramach interpretacyjnych, a także aluzyjność 
przekazu (Gili \& Maddalena, 2018). Pominięcia są zaś celowym wykluczeniem lub umiejscowieniem na drugim planie istotnych informacji dla zrozumienia określonego faktu, zjawiska bądź problemu. Ten rodzaj półprawd uwidacznia się w „kłamaniu bez kłamania”. Mechanizm ten trudno zdemaskować. Podobnie jak zafałszowania, pominięcia - poprzez decyzje autora komunikatu dotyczące tego, czego w informacji nie eksponować - wpływają na zawartość wiadomości. Z tego powodu ich odbiorca nie jest w stanie dowiedzieć się z tekstu, co dokładnie zostało pominięte w przekazie, nawet po jego starannej analizie (Gili \& Maddalena, 2018).

Próby zastosowania przez nadawcę przekazu powyższych form manipulacji jako ewentualnego klucza medialnych interpretacji doktrynalnych fundamentów religii będą przynosić etyczne konsekwencje dla oceny wiarygodności zmediatyzowanego przekazu. Faktoidy, zafałszowania i pominięcia stanowią oczywiste uchybienia koncepcji prawdy korespondencyjnej. Źródła doktrynalne mają charakter nadprzyrodzony i w konsekwencji niepodlegający ludzkim renegocjacjom czy ustaleniom na drodze konsensusu. Jakiś obszar dla dyskusji, choć w określonych granicach, pozostawia kwestia interpretacji dogmatów. Należy jednak zauważyć, że światopoglądowy pluralizm oraz mediatyzacja przekazu są cechami charakterystycznymi współczesnego społeczeństwa, jego myślenia i funkcjonowania. Dogmaty dotyczące prawd wiary i innych niezmieniających się determinantów religii nie dostosowują się do opinii większości. W przypadku sposobu ich relacjonowania przez media dopuszczalne są dwie oceny przekazu: zgodność lub niezgodność z prawdą. Wspomniana dychotomia będzie sprzyjać narastaniu napięcia pomiędzy powyższymi perspektywami odmiennego spojrzenia na doktrynalne podstawy religii. Jak zauważa M. Jakubiec, istnieje wiele religii, które roszczą sobie pretensje do wyłącznej prawdziwości. Jest to szczególnie obecne w trzech największych systemach monoteistycznych: judaizmie, chrześcijaństwie i islamie (Jakubiec, 2015). Za nieetyczne, ponieważ niewiarygodne i niemożliwe do zrealizowania, należałoby uznać takie przekazy mediów, które prezentują ewentualne dyskusje dotyczące treści doktryn religijnych pomiędzy przedstawicielami różnych religii jako osiągalne w wypracowaniu wspólnego stanowiska doktrynalnego. Poszukiwania stanowiska koncyliacyjnego pomiędzy religiami nie mogą być prowadzone na wzór Habermasowskiego ideału poszukiwania idealnej sytuacji komunikacyjnej, ponieważ należy wziąć pod uwagę w ewentualnym poszukiwaniu stanowiska koncyliacyjnego fakt odmiennych, nie do pogodzenia dogmatycznych różnic religii.

Dobrym przykładem dowodzącym obecności fake newsów w informacyjnych serwisach religijnych jest medialny obraz kryzysu uchodźczego drugiej dekady XXI w. i powiązane z tym próby narzucenia opinii publicznej zniekształconego obrazu religii islamu (Bulska, 2014; Homoncik, 2018). W. Przyczyna i A. Załazińska dowodzą, że polska prasa o tematyce religijnej zniekształciła przekaz papieża Franciszka dotyczący postawy Polaków wobec uchodźców podczas jego wizyty w Polsce w dniach 26-31 lipca 2016 r. Dominowały odmienne interpretacje społecznego nauczania papieża: 
Jedni bezpośrednio przywołują jego słowa o konieczności pomocy uchodźcom, drudzy starają się je jednak relatywizować. Relatywizacja ta wiąże się z poszukiwaniem, jak się wydaje, usprawiedliwienia dla odmiennych poglądów (rozróżnienia między uciekinierami a emigrantami zarobkowymi), z próbą rozmycia konkretnego apelu o pomoc (sugeruje się, że apel dotyczy wszystkich potrzebujących, a nie tylko uchodźców) lub z niedostrzeganiem problemu (rzekoma ksenofobia). (Przyczyna \& Załazińska, 2017, s. 98)

Odejście od korespondencyjnej definicji prawdy jest dostrzegalne w kulturze postprawdy i postmodernizmu, które niosą za sobą istotne konsekwencje dla sposobu wypełniania obowiązków profesjonalnych przez dziennikarzy zajmujących się agendą tematów religijnych. Mediatyzacja życia społecznego, a więc także mediatyzacja życia religijnego, jest w dużej mierze naznaczona powyższymi trendami kulturowymi. Niechlubnym standardem w mediach mainstreamowych jest manipulowanie i kreowanie rzeczywistości w postaci pseudoinformowania i hiperrzeczywistości (Guzik, 2018).

Jak zauważa M. Wieczorkowski, pojęcie postprawdy wyraża świadomość tego, iż „współczesna kultura, mass media i różnorakie instytucje za cel swego działania obrały sobie wytwarzanie prawdy polegające na forsowaniu swojej wersji zdarzeń wbrew temu, co potocznie nazywamy faktami” (Wieczorkowski, 2018, s. 253). Koncepcja postprawdy, kreując podział na prawdę obiektywną i prawdę wytwarzaną - iluzoryczną, wskazuje, że równolegle istnieją: (1) obszar wiedzy, który jest odkrywany przez człowieka oraz (2) obszar wiedzy, który jest ustalany przez człowieka na podstawie kryteriów subiektywnych. Tak pojęte kryterium prawdziwości odnoszone do doktrynalnych kwestii religii wyznacza przynajmniej dwie możliwe drogi. Pierwszą z nich jest droga odkrywania prawd objawionych i jednocześnie uznania autorytetu boga czy bóstwa jako ich źródła, a zatem droga, na której zachodzi legitymizowanie i interpretacja prawd religijnych przez przywódcę religijnego. Druga z możliwości, legitymizująca koncepcję postprawdy, zakłada tak dalece wysoki stopień dowolności wykładni prawd religijnych, że trudno ją uznać za znajdującą się w granicach oficjalnej doktryny danej religii. Łatwo dostrzec, że pierwsza z powyższych dróg umożliwia realizację deontologicznych zasad dziennikarstwa (akceptując korespondencyjną koncepcję prawdy), druga zaś - naznaczona subiektywizmem - uniemożliwia implementację reguł etyki profesjonalnej (odrzuca bowiem Tomaszową adaequatio rei et intellectus). M. Lakomy i K. Oświecimski (2018) zwracają uwagę, że media społecznościowe, które są jednym z najważniejszych, ale jednocześnie zwodniczym źródłem wiedzy o świecie dla pokolenia millenialsów, stają się przestrzenią pozbawioną grawitacji etyki prawdy, wciągającą odbiorcę w chocholi taniec bez punktów odniesienia.

Jak słusznie zauważa A. Szahaj (2004), postmodernizm jest nurtem filozoficznym i kulturowym ostatnich dekad XX stulecia. Cechuje go: odejście od paradygmatu produkcji na rzecz paradygmatu konsumpcji; wzrastające zróżnicowanie stylów życia; pluralizm przekonań i światopoglądów, ich prywatyzacja i subiektywizacja; synkretyzm akceptowanych przekonań religijnych, znamionujący pojawieniem się - poza 
instytucjonalnym wymiarem kościołów i wspólnot wyznaniowych - tzw. nowej duchowości; estetyzacja życia; wzrastająca tolerancja dla odmienności; wielokulturowość; dominująca pozycja mediów i kreowanych przezeń wizji świata; niespójność wewnętrzna kultury współczesnej.

Wszystkie największe religie świata odrzucają cechy kultury postmodernizmu oraz głoszą wartość dobrowolnego wyrzeczenia się dóbr materialnych i radykalnej ascezy jako drogi do wyzwolenia i intensyfikacji sił duchowych (Chuda, 2011). Islam, chrześcijaństwo, hinduizm i judaizm precyzują powinności etyczne swoich członków, które są spisane w świętych księgach tychże religii monoteistycznych oraz są wpisane $\mathrm{w}$ ich tradycję. Wzorem postępowania dla muzułmanów jest aksjologiczno-etyczny system słusznego postępowania oraz szariat, czyli islamski system prawno-legislacyjny, w którym precyzyjnie określono zasady prawnego postępowania muzułmanów na płaszczyźnie nakazowo-zakazowej (Leźnicki, 2013). Dla wyznawców judaizmu model postępowania zapisany jest w Dekalogu, stanowiącym część tzw. teofanii synaickiej (Jodzio, 2009). Dla chrześcijan kryterium postępowania stanowi życie samego Chrystusa, będące praktyczną realizacją Kazania na Górze oraz przykazania miłości Boga i bliźniego (Kudasiewicz, 2009). Wyznawcy hinduizmu normatywne i aksjologiczne podstawy życia czerpią ze świętych ksiąg Shruti i Smrti (Singh, 2020). Na przykład kwestia życia ludzkiego jako wartości jest obecna we wszystkich powyższych religiach (Jureńczyk, 2010; Tokarczyk, 2012; Lubiński, 2018) i nie może podlegać „negocjacjom” czy też dowolnym formom interpretacji ze strony trendów postmodernistycznych silnie obecnych w instytucjach medialnych.

Namysł nad etycznymi wymiarami mediatyzacji życia religijnego powinien obejmować także pytanie o to, czy media legitymizują istnienie wartości nienegocjowalnych. Dla katolików takimi wartościami, oprócz ochrony życia ludzkiego, są również poszanowanie i wsparcie naturalnej struktury rodziny, zbudowanej na fundamencie sakramentalnego związku mężczyzny i kobiety, oraz ochrona prawa rodziców do wychowania własnego potomstwa (Leśniczak, 2019).

\section{Determinanty życia religijnego w przestrzeni mediów}

Do istotnych determinantów życia religijnego należy zaliczyć tożsamość i wynikającą z niej autodeklaratywność wiary, formalną przynależność osoby do danej religii oraz indywidualne i wspólnotowe praktyki religijne. Medialne reprezentacje powyższych cech $w$ różnym stopniu odzwierciedlają rzeczywistość. $Z$ etycznego punktu widzenia istotną kwestią jest poznanie intencji osób i instytucji, które są odpowiedzialne za nadawanie przekazu do odbiorcy, a także ocena, czy i w jakim stopniu jest on zgodny z podstawowymi zasadami deontologii dziennikarskiej (np. z zasadą prawdy czy zasadą obiektywizmu). Jest to zadanie wymagające dużej atencji, któremu pomaga ocena linii redakcyjnej pisma, w którym jest zatrudniony dziennikarz, 
oraz analiza zawartości publikowanych treści, wskazująca choćby na stosowane ramy interpretacyjne.

Na przykładzie Kościoła katolickiego można stwierdzić, że tożsamość i autodeklaratywność wiary wiąże się z wolnym i świadomym przyjęciem depozytu wiary, potwierdzanym następnie w życiu sakramentalnym i dokonującym się w instytucjonalnym Kościele. W szeroko pojętej religii powyższa tożsamość związana jest z akceptacją ogółu prawd i norm, które definiują przynależność do danej religii, a także z określonymi czynnościami kultu. Wiele zmediatyzowanych treści odnoszących się do determinantów życia religijnego jest obecnych w mediach, jak choćby programy wzbogacające wiedzę religijną, transmisje medialne z największych świąt religijnych czy relacje z życia instytucji religijnych. Jednak nie wszystkie formy życia religijnego $\mathrm{w}$ wersji zmediatyzowanej mogą być uznane za tożsame $\mathrm{z}$ wersją niezapośredniczoną, np. sakramenty święte w Kościele katolickim (Bartocha, 2019). Właściwe rozumienie i wykorzystanie mediów przez liderów religijnych świadczy o ich odpowiedzialności oraz dowodzi, że procesy mediatyzacji dotyczące życia religijnego mają określone granice użyteczności i stosowalności. Słusznie zauważa N. González Gaitano (2016), że kwestie wiary i posłuszeństwa w Kościele katolickim nie podlegają „medialnym” dyskusjom i interpretacjom, dlatego $\mathrm{w}$ tym przypadku procesy mediatyzacji życia religijnego odgrywają istotną rolę na poziomie transmisji komunikatu od nadawcy do odbiorcy. Z kolei w przypadku kwestii pastoralnych użyteczność procesu mediatyzacji odnosi się również do poziomu interpretacji.

Przywódcy religijni bez wątpienia dostosowują się do realiów, w których oddziaływanie mediów nabiera coraz większego znaczenia. Jest to konsekwencja mediatyzacji. Warto zauważyć, że specyfika religijnego przekazu wymaga od ich nadawców nie tylko wiedzy i doświadczenia z zakresu nauk o komunikowaniu, lecz także podstawowej wiedzy religijnej. Wyraża się to choćby w trafności komentarzy do transmitowanych czynności kultu religijnego. Badania nad zaangażowaniem Kościoła katolickiego w komunikację instytucjonalną dowodzą, że zwierzchnicy wspólnot eklezjalnych rozumieją znaczenie obecności instytucji religijnych w przestrzeni medialnej i komunikowania ze światem, dlatego wykorzystują współczesne środki komunikacji społecznej, w tym nowe media, oraz angażują się w procesy public relations (González Gaitano, 2010; Jarosz, 2016).

Należy podkreślić, że wspólnoty religijne stanowią ważne środowisko wychowawcze, środowisko dialogu kształtujące styl życia, zwłaszcza ludzi młodych. Proces zastąpienia spotkań w świecie rzeczywistym spotkaniami w świecie wirtualnym może prowadzić do zerwania tradycyjnej transmisji wartości oraz do bezrefleksyjnego przejmowania przez odbiorców tendencji obecnych w świecie mediów (Iwanicki, 2017). 


\section{Wnioski}

Postępująca mediatyzacja życia religijnego prowadzi do refleksji nad rolą mediów w życiu religijnym człowieka. Bez wątpienia istotnym aspektem refleksji jest obszar aksjologii. Obecność sacrum w przestrzeni profanum, prawda jako punkt odniesienia medialnych interpretacji doktrynalnych podstaw religii oraz determinanty życia religijnego w przestrzeni mediów to istotne aksjologiczne kwestie związane z mediatyzacją życia religijnego. Perspektywa filozoficzna uzupełnia horyzont komunikologiczny w lepszym zrozumieniu zmediatyzowanego przekazu. Refleksje badawcze uwyraźniły potrzebę precyzyjnych ujęć definicyjnych stosowanych w etyce dla ich jednoznacznego interpretowania przez nadawców i odbiorców przekazu. Korespondencyjna definicja prawdy może stanowić punkt odniesienia w pytaniu o rzetelność informowania oraz w wypracowaniu modelu formacji dziennikarskiej w zakresie informowania o religii. Religijne kwestie o charakterze doktrynalnym domagają się od mediów wierności przekazu, pozostałe zaś pozwalają na większą swobodę interpretacyjną.

\section{Bibliografia}

Bachura, J. (2011). O sytuacji komunikacyjnej współczesnego słuchowiska - wybrane zagadnienia. Acta Universitatis Lodziensis. Folia Litteraria Polonica, 13, 88-95.

Bartel, T. (2007). Metafizyczna interpretacja definicji: veritas est adaequatio rei et intellectus u Tomasza z Akwinu. Przeglad Filozoficzny - Nowa Seria, 1, 111-122.

Bartocha, W. (2019). Liturgia „zmediatyzowana” w świetle Dyrektorium Konferencji Episkopatu Polski w sprawie celebracji Mszy świętej transmitowanej przez telewizję. Łódzkie Studia Teologiczne, 4, 55-69.

Bąkowicz, K. (2019). Wprowadzenie do definicji i klasyfikacji zjawiska fake newsa. Studia Medioznawcze, 20(3), 280-289. doi:10.33077/uw.24511617.ms.2019.2.106

BBC News. (2020). Coronavirus: Iraq reports first two confirmed deaths as fears rise. Pobrane z: www.bbc.com/news/world-middle-east-51751952

Bulska, P. (2014). Medialne reprezentacje islamu na łamach wybranych tygodników opinii: „Gościa Niedzielnego” i „Newsweek Polska”. W: I. Adamczyk, T. Barańska, M. Kłagisz, \& M. Kurcwald (red.), Percepcja cywilizacji islamu w kulturze Zachodu (s. 91-10). Kraków: AT Wydawnictwo.

Burke, D. (2020). The great shutdown 2020: What churches, mosques and temples are doing to fight the spread of coronavirus. Pobrane $\mathrm{z}$ : https://edition.cnn.com/2020/03/14/world/churches-mosques-temples-coronavirus-spread/index.html

Chuda, M. (2011). Ubóstwo ekskluzywne. Ethos. Kwartalnik Instytutu Jana Pawła II KUL, 4, $327-329$.

Chulov, M. (2020). Saudi Arabia closes two holiest shrines to foreigners as coronavirus fears grow. Pobrane z: www.theguardian.com/world/2020/feb/27/saudi-arabia-coronavirus-shrines-pilgrims-hajj-bans

Eliade, M. (1999). Sacrum i profanum. O istocie religijności. Warszawa: Wydawnictwo Aletheia. 
Furman, W. (2017). Fake news i post-truth: dwa nowe zjawiska w dziennikarstwie czy tylko dwa nowe terminy? Visnyk Natsional'noho universytetu «L'vivs'ka politekhnika». Seriya: Zhurnalist.'ski nauky, 883, 57-61. doi:10.23939/sjs2017.01.061

Gili, G. (2001). Il problema della manipolazione: peccato originale dei media? Milano: FrancoAngeli.

Gili, G., \& Maddalena, G. (2018). Post-verità e fake news: radici, significati attuali, inattesi protagonisti e probabili vittime. Media Education Studi, ricerche, buone pratiche, 9(1), 1-16.

González Gaitano, N. (2010). Public Opinion and the Catholic Church. Otázky žurnalistiky, $53(1-2), 26-40$.

González Gaitano, N. (2016). Public opinion in the Church: A communicative and ecclesiological reflection. Church, Communication and Culture, 1(1), 173-205. doi:10.1080/23753234.201 6.1238559

Guzek, D. (2013). Reklama w działaniach instytucji religijnych w Polsce. Chorzowskie Studia Polityczne, 6, 311-326.

Guzek, D. (2015). Mediatyzacja religii: analiza pojęcia. W: E. Borkowska, A. Pogorzelska-Kliks, \& B. Wojewoda (red.), Przestrzenie komunikacji. Technika, język, kultura (s. 69-78). Gliwice: Wydawnictwo Politechniki Śląskiej.

Guzik, A. (2018). Postmodernizm, postprawda, posteksperci w mediach mainstreamowych. W: T. Grabowski \& M. Lakomy (red.), Postprawda jako zagrożenie dla dyskursu publicznego (s. 143-162). Kraków: Wydawnictwo Naukowe Akademii Ignatianum.

Habermas, J. (2002). Wierzyć i wiedzieć. Znak, 568, 8-21.

Hepp, A., Hjarvard, S., \& Lundby, K. (2010). Mediatization - Empirical perspectives: An introduction to a special issue. Communications, 35(3), 223-228. doi:10.1515/comm.2010.012

Hjarvard, S. (2011). The mediatisation of religion: Theorising religion, media and social change. Culture and Religion, 12(2), 119-135. doi:10.1080/14755610.2011.579719

Homoncik, T. (2018). Polskie portale informacyjne o muzułmańskich kobietach w obliczu zwiększonego zainteresowania konwersją na islam. Młoda Humanistyka, 12(2). Pobrane z: www.humanistyka.com/index.php/MH/article/view/181

Hoover, S. (2006). Religion in the Media Age. London: Routledge.

Iwanicki, J. (2017). Mediatyzacja treści religijnych w kulturze internetowej i popularnej. Humaniora. Czasopismo Internetowe, 2, 17-28.

Iwaszko, N. (2010). Nowe media i współczesne dziennikarstwo. Zeszyty Gdańskie, 5, 151-163.

Jakubiec, M. (2015). Doktryny religijne a stanowienie prawa w dobie światopoglądowego pluralizmu. Acta Erasmiana, 8, 227-235.

Jarosz, T. (2016). Religijne public relations - zarządzanie siecią eklezjotwórczych relacji i więzi. Studia Medioznawcze, 4, 27-36. doi:10.33077/uw.24511617.ms.2016.67.430

Jęczeń, A. (2011). Profanacja wartości religijnych we współczesnych mediach. Biuletyn Edukacji Medialnej, 1, 118-126.

Jodzio, H. (2009). Społeczny kontekst i historyczne źródła Dekalogu. Teologia praktyczna, 10, 191-208. doi:10.14746/tp.2009.10.14

Judycki, S. (2001). O klasycznym pojęciu prawdy. Roczniki Filozoficzne, 1, 25-62.

Jureńczyk, Ł. (2010). Znaczenie ahimsy w życiu społecznym Hindusów. W: M. Bednarz \& W. Jurkiewicz (red.), Jeden świat, wiele kultur. Refleksje nad kulturowymi aspektami globalizacji (s. 19-32). Bydgoszcz: Wydawnictwo KPSW.

KAI. (2020). Kościót na świecie wobec pandemii koronawirusa. Pobrane z: https://ekai.pl/kosciol-na-swiecie-wobec-pandemii-koronawirusa

Kamiński, S., \& Zdybicka, Z. (1974). Definicja religii a typy nauk o religii. Roczniki Filozoficzne, 22(1), 103-160. 
Kopecka-Piech, K. (2011). Koncepcje konwergencji mediów. Studia Medioznawcze, 3, 11-26. Kopecka-Piech, K. (2015). Wymiary i skutki saturacji medialnej w przestrzeniach otwartych i zamkniętych na przykładzie analiz centrum handlowego Sky Tower i projektu PIWO. Studia Medioznawcze, 4, 51-63. doi:10.33077/uw.24511617.ms.2015.63.509

Kudasiewicz, J. (2009). Jezus Chrystus a dziedzictwo prawne Starego i Nowego Testamentu. Kieleckie Studia Teologiczne, 8, 93-104.

Kurdupski, M. (2020). Duży wzrost oglądalności mszy świętych w telewizji. Pobrane z: www. wirtualnemedia.pl/artykul/duzy-wzrost-ogladalnosci-mszy-swietych-w-telewizji-analiza

Lakomy, M., \& Oświecimski, K. (2018). Postprawda a filozofia, nauki o mediach i nauka społeczna Kościoła katolickiego. Wprowadzenie. W: T. Grabowski, M. Lakomy, K. Oświecimski, \& A. Pohl (red.), Postprawda. Spojrzenie krytyczne (s. 9-24). Kraków: Wydawnictwo Ignatianum.

Leśniczak, R. (2011). Dziennikarz i informacja - integralny model formacji dziennikarskiej. Łódzkie Studia Teologiczne, 1, 181-205.

Leśniczak, R. (2019). Komunikowanie polityczne Franciszka na temat wartości nienegocjowalnych. Analiza orędzi papieskich na Światowy Dzień Migranta i Uchodźcy (2014-2018) oraz ich zmediatyzowany przekaz na portalu wpolityce.pl. Łódzkie Studia Teologiczne, 1, 97-113.

Leźnicki, M. (2013). Wartość życia u podstaw (bio)etyki. Studia Ecologiae et Bioethicae, 11(3), 51-70. doi:10.21697/seb.2013.11.3.03

Lisowska-Magdziarz, M. (2006). Analiza tekstu w dyskursie medialnym. Przewodnik dla studentów. Kraków: Wydawnictwo Uniwersytetu Jagiellońskiego.

Löhr, G. (1993). Rudolf Otto und das Heilige. Zeitschrift für Religions-und Geistesgeschichte, 2, 113-135. doi:10.1163/157007393X00186

Lövheim, M., \& Hjarvard, S. (2019). The mediatized conditions of contemporary religion: Critical status and future directions. Journal of Religion, Media and Digital Culture, 8(2), 206-225. doi:10.1163/21659214-00802002

Lubiński, P. (2018). Prawo do życia a ataki samobójcze w islamie i prawie międzynarodowym. Annales Universitatis Paedagogicae Cracoviensis. Studia de Securitate, 8, 54-64. doi:10.24917/20820917.8.4

Motak, D. (2010). Religia - religijność - duchowość. Przemiany zjawiska i ewolucja pojęcia. Studia Religiologica. Zeszyty Naukowe Uniwersytetu Jagiellońskiego, 43, 201-218.

Nasrullah, H. (2020). Mosques suspend congregational activities in the fight against coronavirus. Pobrane z: http://muslimnews.co.uk/newspaper/home-news/37556-2

Otto, R. (2004). Das Heilige: über das Irrationale in der Idee des Göttlichen und sein Verhältnis zum Rationalen. München: C.H. Beck.

Pisarek, W. (2006). Mediatyzacja. W: W. Pisarek (red.), Słownik terminologii medialnej (s. 118). Kraków: Universitas.

Przyczyna, W., \& Załazińska, A. (2017). Wpływ mediów na recepcję wątków społecznych zawartych w przemówieniach papieża Franciszka podczas Światowych Dni Młodzieży w Krakowie. Poznańskie Spotkania Językoznawcze, 33, 91-104. doi:10.14746/psj.2017.33.8

Ptaszek, G. (2014). Pomiar indywidualnych kompetencji medialnych. Pytania i problemy. Kultura Popularna, 3, 6-17.

Rogińska, M. (2014). Sacrum ponowoczesne. Nauka i nowa duchowość w poszukiwaniu całości. Annales Universitatis Paedagogicae Cracoviensis. Studia Sociologica, 1(6), 51-68.

Selsky, A. (2020). Houses of worship gain audience by going online during virus. Pobrane z: https:// abcnews.go.com/Health/wireStory/houses-worship-gain-audience-online-virus-70721892

Singh, P. (2020). Shruti and Smriti (śruti and smrti). W: R.B. Nair, \& P.R. de Souza (Eds.), Keywords for India: A Conceptual Lexicon for the $21^{\text {st }}$ Century (s. 332-333). London: Bloomsbury Academic. 
Soler, J.P. (2018). Chi dobbiamo incolpare per la crisi delle fake news? Tre fattori in gioco sulla verità online. Metodologia Didattica e Innovazione Clinica - Nuova Serie, 26(1), 19-26.

Stępniak, K. (2018a). Motywy religijne w komercyjnym przekazie reklamowym a sacrum w przekazie religijnym. Studia Medioznawcze, 2, 85-97. doi:10.33077/uw.24511617.ms.2018.0.264

Stępniak, K. (2018b). Reklama religijna jako odrębny rodzaj reklamy. Zeszyty Prasoznawcze, 61(2), 327-341. doi:10.4467/22996362PZ.18.021.9116

Szahaj, A. (2004). Postmodernizm. W: B. Szlachta (red.), Słownik społeczny (s. 935-936). Kraków: Wydawnictwo WAM.

Tokarczyk, R. (2012). Prawa narodzin, życia i śmierci. Podstawy biojurysprudencji. Warszawa: Wolters Kluwer.

Vahland, J. (2001). Max Webers entzauberte Welt. Würzburg: Königshausen \& Neumann.

Vatican News. (2020). Celebrating a unique Easter with Pope Francis during Covid-19. Pobrane z: www.vaticannews.va/en/vatican-city/news/2020-04/celebrating-a-unique-easter-with-popefrancis-during-covid-19.html

Wieczorkowski, M. (2018). Postprawda jako skutek kryzysu oświeceniowego Rozumu. W: T. Grabowski, M. Lakomy, K. Oświecimski, \& A. Pohl (red.), Postprawda. Spojrzenie krytyczne (s. 253-278). Kraków: Wydawnictwo Ignatianum. 